\title{
Malignant mesothelioma in construction workers: the Apulia regional mesothelioma register, Southern Italy
}

\author{
L. Vimercati1* ${ }^{*}$, D. Cavone ${ }^{1}$, A. Caputi ${ }^{1}$, M. C. Delfino ${ }^{1}$, L. De Maria' ${ }^{1}$ G. M. Ferri ${ }^{1}$ and G. Serio ${ }^{2}$
}

\begin{abstract}
Objective: Asbestos was widely used in construction in both a friable and a compact form until the 1990s, before its use was banned. Today, many of these materials are still in situ and represent a source of risk for construction workers. The objective of the study was to analyse the cases of mesothelioma arising among construction workers registered in the Apulia regional register of mesothelioma.

Results: For the period 1993-2018, there were 178 male cases, and 10.2\% of the cases were present in the regional register. The average age at diagnosis was 64.7 years. The site was pleural in $96.06 \%$ of cases, with a diagnosis of certainty in $86.5 \%$ of the total cases and $61.8 \%$ of cases with epithelial histology. The average latency is 43.9 years. In 75.2\% of cases, the exposure began between 1941 and 1970, with an average duration of 24.3 years. The age at the start of exposure in 68.5\% of cases is between 8 and 20 years. The ORs were 2.5 (C.I. 95\% 1.01-6.17) for the epithelioid histotype and the high duration of exposure. The data underline the need for prevention and information on all activities involving construction workers in which asbestos-containing materials are still used.
\end{abstract}

Keywords: Asbestos, Construction, Workers, Malignant mesothelioma, Compensation, Work-related cancer, Mesothelioma register

\section{Introduction}

Construction is one of the most dangerous industries worldwide. The health risks of construction workers depend on job tasks, each with a specific associated risk and exposure, but these workers are also passively exposed to risks produced by nearby co-workers [1-3]. There are many known carcinogens used in the construction industry [1]. Moreover, work injury and specific exposures to disease are important risk factors for the development of chronic diseases among construction workers given the nature of the work (temporary, manual and outdoors), as well as among other workers not in the

\footnotetext{
*Correspondence: luigi.vimercati@uniba.it

${ }^{1}$ School of Medicine, Interdisciplinary Department of Medicine (DIM),

Ramazzini Occupational Medicine Section, "Policlinico" University Hospital,

UOC of Occupational Medicine, University of Bari "A. Moro", Piazza G,

Cesare 11, 70124 Bari, Italy

Full list of author information is available at the end of the article
}

construction sector who are exposed to the same risks [4-18].

Asbestos has been widely used in construction, and a series of reports have been produced on asbestos-related diseases in these workers. These workers may often be unaware of their exposure to asbestos, as in the case of indirect exposure among certain types of workers, such as carpenters, electricians, plumbers, and welders, if they were on-site during insulation activities [19].

An increased risk of mesothelioma and asbestosrelated pleural disease was reported in construction workers [20-25], and the adjusted odds ratios for lung cancer and mesothelioma were also described among workers who engaged in high levels of smoking [26-29]. Engholm [30] reported an SIR of 3.16 statistically significant (SS) for pleural mesothelioma among Swedish construction workers. In a cohort of construction workers, Dement [31] found an SMR of 5.93 SS for mesothelioma. An updated follow-up of this cohort [32] found an SMR of 6.86 SS for mesothelioma. Rolland [33] found 
a high risk of pleural mesothelioma among construction workers other than insulators, and especially for plumbers and pipe fitters, bricklayers, tile setters, carpenters and other construction workers not elsewhere classified (n.e.c.), with an OR of 3.46 SS. Stocks [34] found mesothelioma SRRs of 7.1 SS for male UK construction industry workers aged below 65 years. The same author [35] found a significantly increased incidence in pipe fitters (4.5), electrical workers (2.7), plumbing and heating engineers (2.3), carpenters and joiners (2.7), scaffolders (12) and labourers (n.e.c. (3.3). Järvholm [36] reported that in a cohort of 367,568 Swedish construction workers, there were 419 cases of pleural mesothelioma between 1972 and 2009. In a cohort of 17,345 sheet metal workers, Welch [37] found an overall mortality that included excess mortality for mesothelioma, with an SMR of 7.34 SS. In Belgium, the mesothelioma mortality was reported to be significantly high among manual workers in the construction sector (SMR 227) [38]. In a study on compensation for ARD in Japan, Sawanyawisuth [39] found that construction had the highest compensated risk ratio.

An [40] reported high ARD claims made to the Korea Workers' Compensation and Welfare Service in the construction sector. Tomasallo [41] found increased odds of mesothelioma in Wisconsin among construction workers.

Peritoneal mesothelioma in the construction industry in Sweden was described by Malkerr in [42], especially among insulation workers, and by Fonte [43] in a case involving workers in the building industry aged 14-55 years who had been cutting and shaping asbestos-containing cement panels. Long-term exposures can induce peritoneal mesothelioma, even in subjects with environmental exposures [44]. Because there is general consensus that malignant mesothelioma (MM) can develop even after short exposures to very low levels of asbestos, there is no evidence of a threshold level below which there is no risk and that the risk increases with the intensity and duration of exposure [45-47].

In this study, we analyse the cases of mesothelioma arising among construction workers registered in the Apulia regional register of mesothelioma.

The regional register records the mesothelioma cases starting in 1993 according to the national guidelines of the RENAM (Italian National Register of Malignant Mesotheliomas). All cases underwent diagnostic revision. The reconstruction of the exposure was performed by means of direct interviews with the subjects or, in the event of death, with the family members using the standardized RENAM questionnaire $[48,49]$. The exposures were classified according to the Istat ATECO 91 classification [50]. Only those with code 45 were analysed, including all subsectors, sectors and tasks. For subjects exposed in more than one work sector, the prevailing sector was considered to provide a longer duration and level of exposure. For all subjects, all other possible exposures to asbestos, including environmental, residential, familial, leisure and non-working exposures, were investigated and excluded. Stata 12 software was used for statistical analysis, univariate analysis and the study of the associations between types of mesothelioma and different variables. Score tests for trend and homogeneity tests were also carried out.

\section{Main text}

The characteristics of mesothelioma cases in the Apulia regional register are reported in Table 1.

The number of cases in the construction sector with exposure periods until 2018 was 178, all occurring in male subjects $(10.2 \%$ of the cases present in the regional register).

The age at diagnosis, the average of which was 64.7 years, was $51-80$ years in $89.8 \%$ of cases. The site was pleural in $96.06 \%$, with a diagnosis of certainty in $86.5 \%$ of the total cases and $61.8 \%$ with epithelial histology.

The average latency is 43.9 years, with $83.1 \%$ of cases having an latency between 21 and 60 years. In $75.2 \%$ the exposure began between 1941 and 1970 and had an average duration of 24.3 years (between 1 and 10 years in $31.5 \%$ of cases). The date of initial exposure correlates with the peak of incident cases (years 2001-2010), equal to $51.6 \%$ of cases registered in the sector.

The age at the start of exposure in $68.5 \%$ is between 8 and 20 years. The exposure was confirmed via direct interview with the subject in $44.9 \%$; in $61.2 \%$, the exposure was classified as occupationally certain or probable, and in only $38.7 \%$ of cases, the exposure was classified as possible.

In total, $21.9 \%$ of the respondents reported having always worked in the construction sector, both in Italy and abroad in Switzerland, France, Germany, Belgium, Libya, Ghana, Venezuela and the USA. Regarding the analysis of the tasks performed and declared during the interview, 48 subjects reported having worked with products containing asbestos (26.9\%). Eighty respondents reported that they carried out the generic job of mason or handyman bricklayer (44.9\%). The remaining 50 respondents played various roles, such as tiler, plasterer, building carpenter, plumber, and electrician.

From the analysis of the risk distribution (ORs) of the histotype according to the duration of exposure, latency and age at diagnosis, an OR of 2.5 (C.I. 95\% 1.01-6.17) was found for the epithelioid histotype and the high duration of exposure (Table 2).

An increased duration of exposure and risk of developing the disease occurred with the more frequent epithelioid histotype, confirming a significant positive trend. 
Table 1 Characteristics of the male mesothelioma cases in the Apulia regional register

\begin{tabular}{|c|c|c|}
\hline Year of diagnosis & Sex (male) & $\%$ \\
\hline 1980-1989 & 8 & 4.5 \\
\hline 1990-1995 & 11 & 6.2 \\
\hline 1996-2000 & 28 & 15.7 \\
\hline $2001-2005$ & 44 & 24.7 \\
\hline 2006-2010 & 48 & 26.9 \\
\hline $2011-2015$ & 25 & 11.04 \\
\hline 2016-2018 & 14 & 7.8 \\
\hline Total & 178 & 100 \\
\hline \multicolumn{3}{|l|}{ Anatomical site } \\
\hline Pleura & 171 & 96.06 \\
\hline Peritoneum & 6 & 3.3 \\
\hline Pericardium & 1 & 0.5 \\
\hline Total & 178 & 100 \\
\hline \multicolumn{3}{|l|}{ Histological type } \\
\hline Epithelioid & 110 & 61.8 \\
\hline Fibrous & 14 & 7.8 \\
\hline Biphasic & 19 & 10.7 \\
\hline NOS & 45 & 25.2 \\
\hline Total & 178 & 100 \\
\hline \multicolumn{3}{|c|}{ Age at diagnosis (years) } \\
\hline $35-40$ & 4 & 2.2 \\
\hline $41-50$ & 8 & 4.5 \\
\hline $51-60$ & 51 & 28.6 \\
\hline $61-70$ & 63 & 35.4 \\
\hline $71-80$ & 46 & 25.8 \\
\hline $81-\omega$ & 6 & 3.3 \\
\hline Total & 178 & 100 \\
\hline \multicolumn{3}{|l|}{ Year start exposure } \\
\hline 1931-1940 & 13 & 7.3 \\
\hline 1941-1950 & 29 & 16.2 \\
\hline 1951-1960 & 49 & 27.5 \\
\hline 1961-1970 & 56 & 31.5 \\
\hline 1971-1980 & 14 & 7.8 \\
\hline 1981-1990 & 9 & 5.05 \\
\hline $1991-2000$ & 8 & 4.5 \\
\hline Total & 178 & 100 \\
\hline \multicolumn{3}{|c|}{ Exposure duration (years) } \\
\hline $0-1$ & 2 & 1.1 \\
\hline $1-10$ & 56 & 31.5 \\
\hline $11-20$ & 23 & 12.9 \\
\hline $21-30$ & 26 & 14.6 \\
\hline $31-40$ & 34 & 19.1 \\
\hline $41-50$ & 30 & 16.8 \\
\hline $51-60$ & 7 & 3.9 \\
\hline Total & 178 & 100 \\
\hline \multicolumn{3}{|c|}{ Age at beginning of exposure } \\
\hline $8-14$ & 43 & 24.1 \\
\hline $15-20$ & 79 & 44.4 \\
\hline $21-30$ & 38 & 21.3 \\
\hline
\end{tabular}

Table 1 (continued)

\begin{tabular}{lcl}
\hline Year of diagnosis & Sex (male) & $\%$ \\
\hline $31-40$ & 10 & 5.6 \\
$41-50$ & 6 & 3.3 \\
$51-\omega$ & 2 & 1.1 \\
Total & 178 & 100 \\
Latency (years) & & \\
$11-20$ & 11 & 6.2 \\
$21-30$ & 15 & 8.4 \\
$31-40$ & 45 & 25.2 \\
$41-50$ & 39 & 21.9 \\
$51-60$ & 49 & 27.5 \\
$61-70$ & 17 & 9.5 \\
$71-\omega$ & 2 & 1.1 \\
Total & 178 & 100 \\
\hline
\end{tabular}

Positive trend results were also found for fibrous histotype and age at diagnosis, although this finding was not SS.

In the RENAM for the years $1993 / 2015$, the building with $15.5 \%$ of the total ascertained exposures is the first economic category for exposure frequency, with 3002 cases $[51,52]$.

In Italy, Carex [53] estimated approximately 70,000 exposures in the construction sector at the beginning of the 2000s. Additionally, the 2017 data of the Italian Institute of Statistics (ISTAT) report 1,309,649 employees in the construction sector [54], and estimates of materials containing asbestos (MCA) in situ were approximately 32 million tons for disposal [55]. It should be emphasized that all these workers may have undergone passive exposure to asbestos during processing. In addition, in the construction sites, the general task of mason/unskilled worker provides for a great interchangeability of tasks/ tasks in practice. In this regard, we must emphasize that $24.1 \%$ of the cases reported here began working between 8 and 15 years without any training/information on risks. This figure can also explain $6.7 \%$ of our cases diagnosed between 35 and 50 years of age.

In Italy, other regional mesothelioma registries have reported an excessive number of MM in the construction sector. Merler [56] in Veneto reported a high prevalence of mesothelioma with a rate of $4.1 \times 10^{5} \times$ year SS. Regarding the latency period, none of the cases reported here have a latency of less than 11 years from first exposure, which is consistent with previous literature. The Helsinki Criteria Consensus report in 1997 established that a minimum of 10 years from the first exposure is required to attribute MM to asbestos exposure [57]. None of the eight cases, with the start of exposure in the years 1991-2000, reported having been aware of the 
Table 2 Risk (ORs) distribution of the different histological types of mesothelioma in construction workers by exposure length, latency period and age at diagnosis

\begin{tabular}{|c|c|c|c|c|c|c|}
\hline Histological type & Variables & Levels (years) & Case & Controls & Odds ratios (LCL-UCL*) & $p^{* *}$ \\
\hline \multirow[t]{9}{*}{ Epithelioid } & Exposure length & $\leq 6$ & 20 & 20 & $1.00(0.00-0.00)$ & \\
\hline & & $7-32$ & 47 & 30 & $1.56(0.73-3.37)$ & \\
\hline & & $>32$ & 30 & 12 & $2.50(1.01-6.17)$ & 0.04 \\
\hline & Latency period & $\leq 34$ & 24 & 13 & $1.00(0.00-0.00)$ & \\
\hline & & $35-53$ & 45 & 35 & $0.69(0.31-1.54)$ & \\
\hline & & $>53$ & 28 & 14 & $1.08(0.43-2.42)$ & 0.82 \\
\hline & Age at diagnosis & $<57$ & 24 & 15 & $1.00(0.00-0.00)$ & \\
\hline & & $57-70$ & 46 & 29 & $0.99(0.45-2.18)$ & \\
\hline & & $>70$ & 27 & 18 & $0.93(0.39-2.23)$ & 0.88 \\
\hline \multirow[t]{9}{*}{ NOS } & Exposure length & $\leq 6$ & 4 & 36 & $1.00(0.00-0.00)$ & \\
\hline & & $7-32$ & 4 & 73 & $0.49(0.12-1.91)$ & \\
\hline & & $>32$ & 1 & 41 & $0.21(0.00-1.55)$ & 0.13 \\
\hline & Latency period & $\leq 34$ & 3 & 34 & $1.00(0.00-0.00)$ & \\
\hline & & $35-53$ & 5 & 75 & $0.75(0.18-3.02)$ & \\
\hline & & $>53$ & 1 & 41 & $0.27(0.00-2.05)$ & 0.26 \\
\hline & Age at diagnosis & $<57$ & 3 & 36 & $1.00(0.00-0.00)$ & \\
\hline & & $57-70$ & 4 & 71 & $0.68(0.15-2.03)$ & \\
\hline & & $>70$ & 2 & 43 & $0.55(0.10-1.80)$ & 0.52 \\
\hline \multirow[t]{9}{*}{ Biphasic } & Exposure length & $\leq 6$ & 5 & 35 & $1.00(0.00-0.00)$ & \\
\hline & & $7-32$ & 9 & 68 & $0.92(0.30-2.83)$ & \\
\hline & & $>32$ & 4 & 38 & $0.73(0.19-2.76)$ & 0.67 \\
\hline & Latency period & $\leq 34$ & 4 & 33 & $1.00(0.00-0.00)$ & \\
\hline & & $35-53$ & 9 & 71 & $1.04(0.31-3.43)$ & \\
\hline & & $>53$ & 5 & 37 & $1.11(0.29-4.17)$ & 0.87 \\
\hline & Age at diagnosis & $<57$ & 4 & 35 & $1.00(0.00-0.00)$ & \\
\hline & & $57-70$ & 9 & 66 & $1.19(0.36-3.91)$ & \\
\hline & & $>70$ & 5 & 40 & $1.09(0.29-4.07)$ & 0.91 \\
\hline \multirow[t]{9}{*}{ Fibrous } & Exposure length & $\leq 6$ & 3 & 37 & $1.00(0.00-0.00)$ & \\
\hline & & $7-32$ & 5 & 72 & $0.85(0.21-3.42)$ & \\
\hline & & $>32$ & 2 & 40 & $0.61(0.11-3.28)$ & 0.60 \\
\hline & Latency period & $\leq 34$ & 2 & 35 & $1.00(0.00-0.00)$ & \\
\hline & & $35-53$ & 6 & 74 & $1.41(0.30-2.20)$ & \\
\hline & & $>53$ & 2 & 40 & $0.87(0.14-1.80)$ & 0.88 \\
\hline & Age at diagnosis & $<57$ & 1 & 38 & $1.00(0.00-0.00)$ & \\
\hline & & $57-70$ & 5 & 70 & $2.71(0.39-4.45)$ & \\
\hline & & $>70$ & 4 & 41 & $3.70(0.52-5.45)$ & 0.23 \\
\hline
\end{tabular}

*Lower and Upper 95\% Cornefield confidence levels

**Probability of Test Chi square ${ }^{2}$ for trend

possible exposure to asbestos. In this group the average latency was 15.5 years (range 11-19), all were employed in maintenance operations and building renovations in civilian homes.

Romeo [58] reported the results of the Lazio register with the highest number of cases among construction workers. D'Agostin [59] reported data from the Friuli Venezia Giulia register, where cases in the construction sector were $12.2 \%$ of all cases registered and had a latency of 46.3 years. Our latency result, 43.9 years, is in accordance with Friuli Venezia Giulia register report, as well as the percentage of cases occupied in construction compared to the total number of cases in our register, $10.2 \%$.

Regarding the cases presented here, 6 peritoneal mesotheliomas, with a media duration of exposure of 19 years, and a pericardial mesothelioma, a subject who had worked in the sector for 16 years in the 1950s and 1960 s, none of these seven cases had particular exposure 
conditions. Except for two peritoneal cases that had always worked in construction, even abroad, in Switzerland for 8 years, in Libya for 3 years and in France for 1 year in the 1960s. Two other peritoneal cases had worked for over 25 years since the 1980s and another for 45 years since the 1960s. To emphasize that none of these seven patients had awareness and remember to have been in contact with asbestos or MCA.

In general, our finding that approximately $10 \%$ of all regional cases are due to asbestos exposure in the construction sector is in agreement not only with Italian data [51, 52] but also with South Korean [60] and German findings $[29,61]$.

\section{Limitations}

A limitation of this study is the lack of analysis of single sectors and risk profiles, which may have differed in intensity, duration, materials used and type of fibre, given the low number of subjects present in our database for each specific task. Conversely, in the literature, the risks were primarily detected in specialized trades, such as insulation workers and plumbers [1], and the main highrisk group among construction workers are considered insulators, carpenters, plumbers and electricians [1, 19, 33, 62-64]. Moreover, Jarvholm [1] noted that the occurrence of pleural mesothelioma among Swedish construction workers showed that secondary exposure or indirect exposures could be the cause of a majority of the mesothelioma cases, which is in accordance with our results on the tasks performed in the cases reported here.

Current occupational exposure among construction workers occurs during the maintenance and remediation of asbestos-containing buildings [19, 65]. Asbestos in older buildings may also be an environmental exposure for occupants and residents during maintenance, renovation and demolition in homes, schools, workplaces and public buildings $[66,67]$.

In Italy, despite the asbestos ban since 1992 (law 257/92), occupational asbestos exposure is still a risk for construction workers, especially if controls are insufficient to protect construction workers or if asbestos removal or waste disposal workers do not take adequate precautions [19, 68, 69]. Investigations of occupational risk factors among construction workers and evaluations of preventive practices are needed to prevent the occurrence of mesothelioma in this hazardous occupation. For example, the early diagnosis of mesothelioma is considered to be important for prognosis, and mesothelin may be useful as a blood tumour marker in the early diagnosis of mesothelioma in a mass examination $[70,71]$, as well as to identify genetic imbalances that could play an important role in the initial development of mesothelioma [72].
These data underline the need for prevention and information on all activities involving construction workers where MCA are still in situ but may be unknown or ignored among these workers.

\section{Abbreviations}

MM: malignant mesothelioma; SS: statistically significant; n.e.c.: not elsewhere classified; ARD: asbestos-related diseases; RENAM: Italian National Register of Malignant Mesotheliomas; ISTAT: Italian Institute of Statistics; MCA: materials containing asbestos.

\section{Acknowledgements}

Not applicable.

\section{Authors' contributions}

LV, DC, GMF, and GS conceived and designed the work. DC, AC, MCD, and LDM performed the work. DC and GMF analysed the data and interpreted the results. LV, DC and AC wrote and revised the manuscript. All authors read and approved the final manuscript.

Funding

Not applicable.

\section{Availability of data and materials}

Data will be provided upon request to Luigi Vimercati (MD, PhD), Interdisciplinary Department of Medicine, Occupational Medicine "B. Ramazzini", University of Bari Medical School, 70124 Bari, Italy. E-mail: luigi.vimercati@uniba.it

\section{Ethical approval and consent to participate}

Informed and written consent was obtained from all participants. All subjects were informed that data from the research protocol would be treated in an anonymous and collective way, with scientific methods and for scientific purposes in accordance with the principles of the Helsinki Declaration.Ethical approval is not necessary because all medical and instrumental examinations were performed according to Italian law concerning the protection of workers exposed to occupational risks (D.Lgs. 81/2008).

\section{Consent for publication}

Not applicable.

\section{Competing interests}

The authors declare that they have no competing interests.

\section{Author details}

${ }^{1}$ School of Medicine, Interdisciplinary Department of Medicine (DIM), Ramazzini Occupational Medicine Section, "Policlinico" University Hospital, UOC of Occupational Medicine, University of Bari "A. Moro", Piazza G, Cesare 11, 70124 Bari, Italy. ${ }^{2}$ School of Medicine, Department of Emergency and Organ Transplantation (DETO), Division of Pathology, University of Bari "A. Moro", Piazza G, Cesare 11, 70124 Bari, Italy.

Received: 24 July 2019 Accepted: 21 September 2019 Published online: 30 September 2019

\section{References}

1. Järvholm B. Carcinogens in the construction industry. Ann N Y Acad Sci. 2006;1076:421-8

2. Suárez Sánchez FA, Carvajal Peláez Gl, Catalá Alís J. Occupational safety and health in construction: a review of applications and trends. Ind Health. 2017;55(3):210-8. https://doi.org/10.2486/indhealth.2016-0108 (Epub 2017 Feb 7. Review).

3. Strickland JR, Wagan S, Dale AM, Evanoff BA. Prevalence and perception of risky health behaviors among construction workers. J Occup Environ Med. 2017;59(7):673-8. https://doi.org/10.1097/JOM.0000000000001051.

4. Machado Susseret N, Briceno-Ayala L, Radon K. Prevalence of low back pain in migrant construction workers in Mar del Plata, Argentina. Am 
J Ind Med. 2019. https://doi.org/10.1002/ajim.23016 (Epub ahead of print).

5. Al-Bouwarthan M, Quinn MM, Kriebel D, Wegman DH. Assessment of heat stress exposure among construction workers in the hot desert climate of Saudi Arabia. Ann Work Expo Health. 2019;63(5):505-20. https ://doi.org/10.1093/annweh/wxz033.

6. Tonnon SC, Robroek SRJ, van der Beek AJ, Burdorf A, van der Ploeg HP, Caspers M, Proper Kl. Physical workload and obesity have a synergistic effect on work ability among construction workers. Int Arch Occup Environ Health. 2019;92(6):855-64. https://doi.org/10.1007/s00420-019-01422 $-7$.

7. Hajaghazadeh M, Marvi-Milan H, Khalkhali H, Mohebbi I. Assessing the ergonomic exposure for construction workers during construction of residential buildings. Work. 2019;62(3):411-9. https://doi.org/10.3233/ WOR-192876.

8. Ragan KR, Buchanan Lunsford N, Thomas CC, Tai EW, Sussell A, Holman DM. Skin cancer prevention behaviors among agricultural and construction workers in the United States, 2015. Prev Chronic Dis. 2019;7(16):E15. https://doi.org/10.5888/pcd16.180446.

9. Jackson JA, Olsson D, Burdorf A, Punnett L, Järvholm B, Wahlström J. Occupational biomechanical risk factors for radial nerve entrapment in a 13-year prospective study among male construction workers. Occup Environ Med. 2019;76(5):326-31. https://doi.org/10.1136/oemed-2018105311 (Epub 2019 Mar 8).

10. Baldassarre A, Dragonieri S, Luisi V, Musti M, Vimercati L. Occupational asthma in a fruit and vegetables vendor. Med Lav. 2016;107(2):87-91.

11. Vimercati L, Gatti MF, Baldassarre A, Nettis E, Favia N, Palma M, Martina GL, Di Leo E, Musti M. Occupational exposure to urban air pollution and allergic diseases. Int J Environ Res Public Health. 2015;12(10):12977-87. https://doi.org/10.3390/ijerph121012977.

12. Bancone C, Bresciani M, Leghissa P, Riva MM, Santini M, Mosconi G. The skin cancer in the construction industry. G Ital Med Lav Ergon. 2012;34(3 Suppl):492-4 (Italian)

13. Campo L, Vimercati L, Carrus A, Bisceglia L, Pesatori AC, Bertazzi PA, Assennato G, Fustinoni S. Environmental and biological monitoring of PAHs exposure in coke-oven workers at the Taranto plant compared to two groups from the general population of Apulia, Italy. Med Lav. 2012;103(5):347-60

14. Vimercati L. Traffic related air pollution and respiratory morbidity. Lung India. 2011:28(4):238. https://doi.org/10.4103/0970-2113.85682.

15. Zedan H, Abd El-Baset HA, Abd-Elsayed AA, El-Karn MF, Madkors HR. Lesional skin vascular endothelial growth factor levels correlate with clinical severity in patients with cement allergic contact dermatitis. East Mediterr Health J. 2010;16(4):420-4.

16. Lorusso A, Vimercati L, L'abbate N. Musculoskeletal complaints among Italian X-ray technology students: a cross-sectional questionnaire survey. BMC Res Notes. 2010;3:114. https://doi.org/10.1186/1756-0500-3-114.

17. Vimercati L, Carrus A, Bisceglia L, Tatò I, Bellotta MR, Russo A, et al. Biological monitoring and allergic sensitization in traffic police officers exposed to urban air pollution. Int J Immunopathol Pharmacol. 2006;19(4 Suppl):57-60

18. Kaukiainen A, Martikainen R, Riala R, Reijula K, Tammilehto L. Work tasks, chemical exposure and respiratory health in construction painting. Am J Ind Med. 2008;51(1):1-8.

19. Mazurek JM, Syamlal G, Wood JM, Hendricks SA, Weston A. Malignant mesothelioma mortality_United States, 1999-2015. MMWR Morb Mortal Wkly Rep. 2017;66(8):214-8. https://doi.org/10.15585/mmwr.mm6608a3.

20. Burkhart G, Schulte PA, Robinson C, Sieber WK, Vossenas P, Ringen K. Job tasks, potential exposures, and health risks of laborers employed in the construction industry. Am J Ind Med. 1993;24(4):413-25 (Review)

21. Bresnitz EA, Gilman MJ, Gracely EJ, Airoldi J, Vogel E, Gefter W. Asbestosrelated radiographic abnormalities in elevator construction workers. Am Rev Respir Dis. 1993;147(6 Pt 1):1341-4.

22. Coggon D, Inskip H, Winter P, Pannett B. Differences in occupational mortality from pleural cancer, peritoneal cancer, and asbestosis. Occup Environ Med. 1995:52(11):775-7.

23. Stern FB, Sweeney MH, Ward E. Proportionate mortality among unionized construction ironworkers. Am J Ind Med. 1997;31(2):176-87.

24. Wang E, Dement JM, Lipscomb H. Mortality among North Carolina construction workers, 1988-1994. Appl Occup Environ Hyg. 1999;14(1):45-58.
25. Robinson CF, Petersen M, Palu S. Mortality patterns among electrical workers employed in the U.S. construction industry, 1982-1987. Am J Ind Med. 1999;36(6):630-7.

26. Fletcher AC, Engholm G, Englund A. The risk of lung cancer from asbestos among Swedish construction workers: self-reported exposure and a job exposure matrix compared. Int J Epidemiol. 1993;22(Suppl 2):S29-35.

27. Kishimoto T, Morinaga K, Kira S. The prevalence of pleural plaques and/or pulmonary changes among construction workers in Okayama, Japan. Am $J$ Ind Med. 2000;37(3):291-5.

28. Koskinen K, Pukkala E, Martikainen R, Reijula K, Karjalainen A. Different measures of asbestos exposure in estimating risk of lung cancer and mesothelioma among construction workers. J Occup Environ Med. 2002:44(12):1190-6.

29. Burdorf A, Dahhan M, Swuste P. Occupational characteristics of cases with asbestos-related diseases in The Netherlands. Ann Occup Hyg. 2003:47:485-92.

30. Engholm G, Englund A. Asbestos hazard in the Swedish construction industry-recent trends in mesothelioma incidence. Scand I Work Environ Health. 2005;31(Suppl 2):27-30.

31. Dement JM, Ringen K, Welch LS, Bingham E, Quinn P. Mortality of older construction and craft workers employed at Department of Energy (DOE) nuclear sites. Am J Ind Med. 2009;52(9):671-82. https://doi.org/10.1002/ ajim.20729.

32. Ringen $K$, Dement J, Welch L, Bingham E, Quinn P, Chen A, Haas S. Mortality of older construction and craft workers employed at department of energy (DOE) nuclear sites: follow-up through 2011. Am J Ind Med. 2015;58(2):152-67. https://doi.org/10.1002/ajim.22406 (Epub 2014 Dec 8).

33. Rolland P, Gramond C, Lacourt A, Astoul P, Chamming's S, Ducamp S, Frenay C, Galateau-Salle F, Ilg AG, Imbernon E, Le Stang N, Pairon JC, Goldberg M, Brochard P, PNSM Study Group. Occupations and industries in France at high risk for pleural mesothelioma: a population-based casecontrol study (1998-2002). Am J Ind Med. 2010;53(12):1207-19. https:// doi.org/10.1002/ajim.20895.

34. Stocks SJ, McNamee R, Carder M, Agius RM. The incidence of medically reported work-related ill health in the UK construction industry. Occup Environ Med. 2010;67(8):574-6. https://doi.org/10.1136/oem.2009.05359 5.

35. Stocks SJ, Turner S, McNamee R, Carder M, Hussey L, Agius RM. Occupation and work-related ill-health in UK construction workers. Occup Med (Lond). 2011;61 (6):407-15. https://doi.org/10.1093/occmed/kgr075 (Epub 2011 Jul 13).

36. Järvholm B, Aström E. The risk of lung cancer after cessation of asbestos exposure in construction workers using pleural malignant mesothelioma as a marker of exposure. J Occup Environ Med. 2014;56(12):1297-301. https://doi.org/10.1097/JOM.0000000000000258.

37. Welch L, Dement J, West G. Mortality among sheet metal workers participating in a respiratory screening program. Am J Ind Med. 2015;58(4):37891. https://doi.org/10.1002/ajim.22421 (Epub 2015 Feb 24).

38. Van den Borre L, Deboosere P. Enduring health effects of asbestos use in Belgian industries: a record-linked cohort study of cause-specific mortality (2001-2009). BMJ Open. 2015;5(6):e007384. https://doi.org/10.1136/ bmjopen-2014-007384.

39. Sawanyawisuth K, Furuya S, Park EK, Myong JP, Ramos-Bonilla JP, Chimed Ochir O, Takahashi K. Compensation for asbestos-related diseases in Japan: utilization of standard classifications of industry and occupations. Asian Pac J Cancer Prev. 2017;18(7):1779-82.

40. An YS, Kim HD, Kim HC, Jeong KS, Ahn YS. The characteristics of asbestosrelated disease claims made to the Korea Workers' Compensation and Welfare Service (KCOMWEL) from 2011 to 2015. Ann Occup Environ Med. 2018;30:45. https://doi.org/10.1186/s40557-018-0256-6 (eCollection 2018).

41. Tomasallo CD, Christensen KY, Raymond M, Creswell PD, Anderson HA, Meiman JG. An occupational legacy: malignant mesothelioma incidence and mortality in Wisconsin. J Occup Environ Med. 2018;60(12):1143-9. https://doi.org/10.1097/JOM.0000000000001461.

42. Malker HS, McLaughlin JK, Weiner JA, Blot WJ, Ericsson JL. Peritoneal mesothelioma in the construction industry in Sweden. J Occup Med. 1987;29(12):979-80. 
43. Fonte R, Gambettino S, Melazzini M, Scelsi M, Zanon C, Candura SM. Asbestos-induced peritoneal mesothelioma in a construction worker. Environ Health Perspect. 2004;112(5):616-9.

44. Serio G, Pezzuto F, Marzullo A, Scattone A, Cavone D, Punzi A, et al. Peritoneal mesothelioma with residential asbestos exposure. Report of a case with long survival (seventeen years) analyzed by Cgh-array. Int J Mol Sci. 2017;18(8):1818. https://doi.org/10.3390/ijms18081818.

45. Pinto C, Novello S, Torri V, Ardizzoni A, Betta PG, Bertazzi PA, et al. Second Italian consensus conference on malignant pleural mesothelioma: state of the art and recommendations. Cancer Treat Rev. 2013;39(4):328-39. https://doi.org/10.1016/j.ctrv.2012.11.004.

46. Magnani C, Fubini B, Mirabelli D, Bertazzi PA, Bianchi C, Chellini E, et al. Pleural mesothelioma: epidemiological and public health issues. Report from the second Italian consensus conference on pleural mesothelioma. Med Lav. 2013;104(3):191-202.

47. Magnani C, Bianchi C, Chellini E, Consonni D, Fubini B, Gennaro V, et al. III Italian consensus conference on malignant mesothelioma of the pleura. Epidemiology, public health and occupational medicine related issues. Med Lav. 2015;106(5):325-32.

48. Nesti M, Adamoli S, Ammirabile F, Ascoli V, Barbieri PG, Cacciarini V, et al. Guidelines for the identification and definition of malignant mesothelioma cases and the transmission to Ispesl by Regional Operating centres. Rome: Ispesl; 2003. https://www.inail.it/cs/internet/docs/renam_guide lines.pdf?section=attivita. Accessed Jun 152019.

49. Chellini E, Merler E, Bruno C, Comba P, Crosignani C, Magnani C, et al. Linee guida per la rilevazione e la definizione dei casi dimesoteliomamaligno e la trasmissione delle informazioni all'ISPESL da parte dei Centri Operativi Regionali. Fogli D'informazione ISPESL. 1996;1:19-106.

50. https://www.istat.it/it/files//2011/03/raccordoateco02_91.pdf. Accessed Sep 162019.

51. Marinaccio A, Binazzi A, Bonafede M, Branchi C, Bugani M, Corfiati M, ReNaM Working Group. II Registro Nazionale dei Mesoteliomi (ReNaM) VI Rapporto. (C2018 INAIL. Tipografia INAIL_Milano, Settembre 2018. https://www.inail.it/cs/internet/docs/alg-pubblregistro-nazionale-mesot eliomi-6-rapporto.pdf. Accessed 11 Jun 2019.

52. Marinaccio A, Binazzi A, Di Marzio D, Scarselli A, Verardo M, Mirabelli D, et al. Pleural malignant mesothelioma epidemic: incidence, modaliteis of asbestos exposure and occupations involved from the Italian national register. Int J Cancer. 2012;130:2146-54.

53. Mirabelli D, Kauppinen T. Occupational exposures to carcinogens in Italy: an update of CAREX database. Int J Occup Environ Health. 2005;11(1):53-63.

54. Italian Institute of Statistics. Database. Enterprises and employees. http:// dati.istat.it/Index.aspx?DataSetCode=DICA_ASIAUE1P. Accessed 11 Jul 2019.

55. Ministero della Salute. Stato dell'arte e prospettive in materia di contrasto alle patologie asbesto-correlate. Quaderni del Ministero della salute 2012. http://www.quotidianosanita.it/allegati/allegato6269534.pdf. Accessed 13 Jun 2019

56. Merler E, Bressan V, Somigliana A. Mesothelioma in construction workers: risk estimate, lung content of asbestos fibres, claims for compensation for occupational disease in the Veneto Region mesothelioma register. Med Lav. 2009;100(2):120-32 (Italian).

57. Concensus report. Asbestos, asbestosis, and cancer: the Helsinki criteria for diagnosis and attribution. Scand J Work Environ Health. 1997;1997(23):311-6.

58. Romeo E, Ascoli V, Ancona L, Balestri A, Scalzo CC, Cavariani F, et al. Occupational exposure to asbestos and incidence of malignant mesothelioma in the Lazio region, years 2001-2009: results of the activities of the regional register. Med Lav. 2013;104(2):115-25 (Italian).

59. D'Agostin F, De Michieli P, Chermaz C, Negro C. Pleural and peritoneal mesotheliomas in the Friuli Venezia Giulia register: data analysis from
1995 to 2015 in Northeastern Italy. J Thorac Dis. 2017;9(4):1032-45. https ://doi.org/10.21037/jtd.2017.03.164.

60. Jung SH, Kim HR, Koh SB, Yong SJ, Chung MJ, Lee CH, Han J, Eom MS, Oh $\mathrm{SS}$. A decade of malignant mesothelioma surveillance in Korea. Am J Ind Med. 2012;55:869-75.

61. Neumann V, Günther S, Müller KM, Fischer M. Malignant mesotheliomagerma mesothelioma register 1987-1999. Int Arch Ouccup Environ Health. 2001;74:383-95.

62. Gilham C, Rake C, Hodgson J, Darnton A, Burdett G, Peto Wild J, Newton M, Nicholson AG, Davidson L, Shires M, Treasure T, Peto J, TIPS Collaboration. Past and current asbestos exposure and future mesothelioma risks in Britain: the Inhaled Particles Study (TIPS). Int J Epidemiol. 2018;47(6):1745-56. https://doi.org/10.1093/ije/dyx276.

63. Hannaford-Turner K, Elder D, Sim MR, Abramson MJ, Johnson AR, Yates $\mathrm{DH}$. Surveillance of Australian workplace based respiratory events (SABRE) in New South Wales. Occup Med (Lond). 2010;60(5):376-82. https ://doi.org/10.1093/occmed/kqq011 (Epub 2010 Mar 22).

64. Nesti M, Marinaccio A, Gennaro V, Gorini G, Mirabelli D, Mensi C, Merler E, Montanaro F, Musti M, Pannelli F, Romanelli A, Tumino R, ReNaM Working Group. Epidemiologic surveillance for primary prevention of malignant mesothelioma: the Italian experience. Med Lav. 2005;96(4):338-46.

65. Olsen NJ, Franklin PJ, Reid A, de Klerk NH, Threlfall TJ, Shilkin K, Musk B. Increasing incidence of malignant mesothelioma after exposure to asbestos during home maintenance and renovation. Med J Aust. 2011;195(5):271-4

66. Gilham C, Rake C, Burdett G, Nicholson AG, Davison L, Franchini A, et al. Pleural mesothelioma and lung cancer risks in relation to occupational history and asbestos lung burden. Occup Environ Med. 2016;73(5):290-9. https://doi.org/10.1136/oemed-2015-103074 (Epub 2015 Dec 29).

67. Vimercati L, Cavone D, Lovreglio P, De Maria L, Caputi A, Ferri GM, Serio G. Environmental asbestos exposure and mesothelioma cases in Bari, Apulia region, southern Italy: a national interest site for land reclamation. Environ Sci Pollut Res Int. 2018;25(16):15692-701. https://doi.org/10.1007/s1135 6-018-1618-x (Epub 2018 Mar 25).

68. Vimercati L, Baldassarre A, Gatti MF, De Maria L, Caputi A, Dirodi AA, Cuccaro F, Bellino RM. Respiratory health in waste collection and disposal workers. Int J Environ Res Public Health. 2016;13(7):631. https://doi. org/10.3390/ijerph13070631.

69. Marsili D, Angelini A, Bruno C, Corfiati M, Marinaccio A, Silvestri S, Zona A, Comba P. Asbestos ban in Italy: a major milestone, not the final cut. Int J Environ Res Public Health. 2017;14(11):1379. https://doi.org/10.3390/ijerp h14111379.

70. Dipalma N, Luisi V, Di Serio F, Fontana A, Maggiolini P, Licchelli B, et al. Biomarkers in malignant mesothelioma: diagnostic and prognostic role of soluble mesothelin-related peptide. Int J Biol Markers. 2011;26(3):160-5. https://doi.org/10.5301/jbm.2011.8614 (Epub 2011 Sep 5).

71. Hirohashi T, Igarashi K, Abe M, Maeda M, Hino O. Retrospective analysis of large-scale research screening of construction workers for the early diagnosis of mesothelioma. Mol Clin Oncol. 2014;2(1):26-30 (Epub 2013 Oct 2).

72. Serio G, Vimercati L, Pennella A, Gentile M, Cavone D, Buonadonna AL, et al. Genomic changes of chromosomes 8p23.1 and 1q21: novel mutations in malignant mesothelioma. Lung Cancer. 2018;126:106-11. https:// doi.org/10.1016/j.lungcan.2018.10.012 (Epub 2018 Oct 27).

\section{Publisher's Note}

Springer Nature remains neutral with regard to jurisdictional claims in published maps and institutional affiliations. 